\title{
Effective Project Management Principles and Strategies in Transportation Infrastructure Projects
}

\author{
Elnaz Safapour ${ }^{1}$, Sharareh Kermanshachi ${ }^{2}$ and Amirhosein Jafari ${ }^{3}$
}

1 Department of Civil Engineering, University of Texas at Arlington, Arlington, USA, elnaz.safapour@mavs.uta.edu

2 Department of Civil Engineering, University of Texas at Arlington, Arlington, USA, (corresponding author), sharareh.kermanshachi@uta.edu

3 Department of Civil Engineering, Louisiana State University, Louisiana, USA, ajafari1@Isu.edu

\begin{abstract}
Departments of Transportation (DOT) are experiencing unprecedented pressure to deliver projects on time and on budget. An obvious response to this pressure is to improve the project delivery process by adopting effective project management principles and strategies. The research team for this study investigated the DOT's implementation level of effective project management practices and strategies for transportation infrastructure projects by first performing a literature review to discover the project management strategies and practices historically used in transportation projects. Then, they designed a survey to identify the general project management practices implemented in the delivery process. They pilot tested the survey, distributed it to state transportation agencies via an online platform, and collected 96 completed surveys. The results revealed that team qualification was ranked the highest of the implementation level of strategies, and that environmental planning and quality management were ranked second and third. The outcomes of this study will help decision-makers and project managers in their assessments and selections of the most useful best practices for delivering an infrastructure transportation project on time, on budget, and with a high level of quality.
\end{abstract}

(c) 2020 The Authors. Published by Budapest University of Technology and Economics \& Diamond Congress Ltd Peer-review under responsibility of the Scientific Committee of the Creative Construction Conference 2020.

Keywords: tansportation infrastructure project, project management strategy, project management principle, design phase, construction phase

\section{Introduction}

In the last decade, there has been a sharp increase in the number of infrastructure transportation projects in the US, and on any given day, a DOT has hundreds of projects of different sizes underway, with the common purpose of ensuring that millions of travelers experience transportation networks that run smoothly. Transportation agencies and project managers are experiencing unprecedented pressure to deliver projects on time and on budget [1]; however, the projects frequently fail to meet owners' expectations in terms of cost and schedule performance [2, 3, 4]. In 2010, Thomsen et al. [5] conducted a study that showed that between $40 \%$ and $50 \%$ of all construction projects fall behind their baseline schedule. When a construction project is delayed, the construction either has to be accelerated, or its completion date has to be extended, which causes cost overruns. An obvious response to this pressure is to improve the project delivery process by adopting the available successful project management practices $[6,7]$. This study attempts to delve deeper into the strategies that are effective for successful project delivery and project management by answering the following questions. 
Q1. What are the most adopted project management principles in infrastructure transportation projects?

Q2. What are the most implemented project management strategies in infrastructure transportation projects?

Project managers will be able to use the findings of this study to assess the managerial practices and strategies of infrastructure transportation projects and select the ones that are most beneficial to preventing schedule delays and cost overruns.

\section{Literature review}

\subsection{Success criteria for a construction project}

Project success is the foundation for monitoring and managing a construction project [8]. Tuman [9] defines construction project success as "having everything turned out as hoped ... anticipating all project requirements and having sufficient resources to meet needs in a timely manner." De Wit [10] describes construction project success as when primary stakeholders, the project team, and end user are completely satisfied with the project outcome. In 1987, Pinto and Slevin [11] stated that a project could be called successful when it has been completed on time and on budget, has met all of the project objectives, and has satisfied the client. Sohail and Baldwin [12] presented five success criteria for projects: schedule, budget, cooperation and partnership, quality, and socioeconomic content. Most researchers believe that measuring the budget, schedule, and quality performance, which have been called the "iron triangle" in project management, is very important to the success of a construction project $[6,13,14,15,16,17]$

Project management plays a critical role in successfully delivering a construction project [18]. In 2008, the PMBOK@GUIDE [19] defined project management as the utilization of knowledge, tools and techniques, and skills for project activities to meet construction project requirements. In 1996, Tan pointed out that most construction projects need to adopt both the art and science of project management and that implementation of an adequate level of tools and technology is necessary or managing a project that can be considered efficient and effective. Owners are usually satisfied with high quality and reasonable quantity provided at the least cost in the least amount of time [20], and achievement of the project success criteria is vital $[21,22]$ to providing this satisfaction.

In 2004, Morrison and Brown [23] presented the following factors that are needed to improve the effectiveness of project management: (1) clarity of project objectives, (2) alignment of project objectives, (3) effective consultation with the client, (4) effective consultation with the end-user, (5) effective project leadership, (6) sufficient qualified human resources, (7) availability of resources, (8) adoption of a novel and systematic project management approach, and (9) an effective project organization and authority structure.

In 2009, Siemiatycki [24] described five best practices and strategies for efficiently managing and improving the cost and schedule performances of a transportation infrastructure project: (1) improvement in the methods of monitoring a project's performance and reporting and sharing the related knowledge and information, (2) improvement in the areas of responsibility and accountability for changes and/or overruns, (3) improvement of workforce qualifications, (4) application of state-of-the art forecasting techniques, and (5) focusing early on plans to be completed.

Although some studies have identified current useful managerial strategies and practices, two knowledge gaps are apparent in the existing literature: (1) a comprehensive study about the implementation level of effective project management strategies adopted for highway, roadway, and bridge projects by DOTs; and (2) a comprehensive study about managerial practices that can improve the efficiency and effectiveness of project management in successfully delivering highway, roadway, and bridge projects. This study attempts to fill those gaps and will benefit state DOT agencies as they identify and adopt successful project management practices and strategies for their transportation infrastructure projects. 


\section{Research framework}

The research framework developed to fulfill the objectives of this study is depicted in Figure 1. It shows that a comprehensive literature review was performed that focused on the managerial issues that DOTs encounter, and effective mitigating strategies and practices that could help them deliver projects on time and on budget. A structured survey was developed, based upon the literature review, and was distributed to the personnel of 52 state DOT agencies. After two follow-up emails, 96 completed surveys were collected, the data was analyzed, and results were obtained.

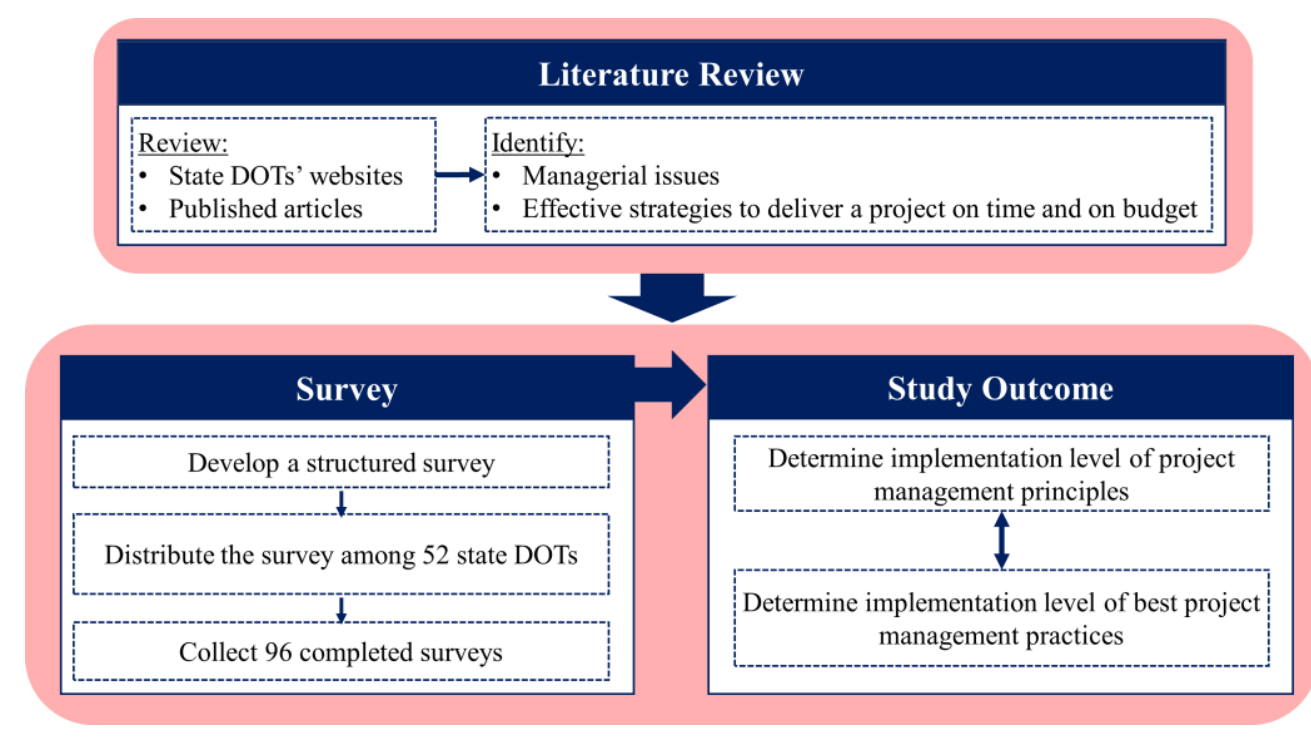

Figure 1. Research Framework

\section{Data collection}

The research team identified potential questions associated with the project's objectives by conducting a comprehensive literature review. Next, they categorized the potential questions into two main categories, managerial issues and project management best practices, and designed the survey, which ultimately covered six categories of questions: general information, project delivery, cost management, time management, project management, and best practices. Four experts and professionals were asked to pilottest it, and after receiving their feedback and suggestions, the research team made the final modifications and finalized the online version.

The research team identified potential respondents from different state DOT agencies and emailed them to ask them to participate in the survey and to share their points of view. After multiple follow-up emails, 96 completed surveys were collected. The demographic information of the respondents presented in Table 1 shows that approximately $90 \%$ of the respondents had more than 10 years of experience with a state DOT agency, and roughly $15 \%$ had been project managers. The regions and the associated frequency of the survey responses are presented in Figure 2, which shows that one or two surveys were completed by respondents located in 14 different state DOT agencies (Washington, Idaho, South Dakota, Nebraska, Minnesota, Oklahoma, Texas, Louisiana, Kentucky, Tennessee, Maine, Vermont, Maryland, and Connecticut). Three or four respondents were located in state DOT agencies in Oregon, lowa, North Carolina, Alabama, and New Mexico, and more than five responses were from state DOT agencies in Florida, Arizona, Utah, Colorado, Virginia, and Ohio. The respondents were asked to reveal the type of project on which they based their answers to the survey questions, and the results showed that $46 \%$ had selected a highway project, $32 \%$ had selected a bridge project, and $22 \%$ had selected a roadway project. 
Table 1. Demographic Information of Survey Respondents

\begin{tabular}{lll}
\hline Position & Experience & Percentage \\
\hline Construction Engineer & More than 10 Years & $48 \%$ \\
Construction Manager & More than 10 Years & $7 \%$ \\
Chief Construction Officer & More than 10 Years & $7 \%$ \\
Administration Director & More than 10 Years & $6 \%$ \\
Construction Supervisor & More than 10 Years & $1 \%$ \\
Contract Manager & More than 10 Years & $1 \%$ \\
Deputy Director & More than 10 Years & $1 \%$ \\
Field Engineer & Less than 5 Years & $4 \%$ \\
& Between 5 and 10 Years & $1 \%$ \\
Project Manager & More than 10 Years & $13 \%$ \\
& Between 5 and 10 Years & $3 \%$ \\
Staff Engineer & More than 10 Years & $4 \%$ \\
Superintendent & Between 5 and 10 Years & $1 \%$ \\
\hline
\end{tabular}

\section{Analysis \& discussion}

\subsection{Effective project management principles}

According to studies conducted by $[25,26]$, project scoping is one of the primary steps in successfully executing the construction of highway projects. Multiple researchers and authors have stated that the level of implementation of the scope definition can considerably affect a project's cost and schedule performance by mitigating the number and cost of change orders $[25,27,28,29]$. This is because the project's needs and risks can be identified and assessed when a construction project is fully defined, facilitating more accurate cost estimates and resulting in fewer change orders at lower cost [30, 31].

The survey participants were given a list of 13 project management principles that had been identified through the existing literature as useful for infrastructure transportation projects and were asked to provide information about their DOT's implementation level of each of them. The results, as shown in Table 2 , indicated that $70 \%$ of them thought that their DOT agencies make an effort to ensure that project scopes are fully defined.

Table 2. also shows that 70\% of the respondents reported that their DOT agencies establish effective communication among DOT staff and have an escalation process to resolve project conflicts and issues. Communication in a construction project refers to the exchange and transfer of data, information, and knowledge among the project's parties and team members [32, 33]; therefore, establishing effective communication enables the timely transfer of knowledge and skills [34, 35]. On the contrary, ineffective communication among the project's staff leads to a lack of timely information and skills, and can result in an increase in the number of design changes and modifications that might ultimately increase the number of schedule delays and cost overruns [36]. In summary, the development of effective communication in a transportation project has the potential to improve the cost and schedule performance. 
Table 2. Implementation of Effective Project Management Principles

\begin{tabular}{|c|c|}
\hline Principles & Percentage \\
\hline Ensure that the project is fully scoped & $70 \%$ \\
\hline $\begin{array}{l}\text { Establish and maintain effective communication among DOT staff; develop an escalation process to resolve } \\
\text { conflicts and issues }\end{array}$ & $70 \%$ \\
\hline $\begin{array}{l}\text { Actively oversee consultants and contractors to ensure work is complete and timely and meets quality } \\
\text { standards and regularly requirements }\end{array}$ & $70 \%$ \\
\hline Participate in partnership meetings & $54 \%$ \\
\hline Know and understand pertinent regulations & $50 \%$ \\
\hline Begin work only after funding authorization has been obtained & $50 \%$ \\
\hline Ensure that the project team has the required qualifications, certifications, and experience & $46 \%$ \\
\hline Develop a project management plan and follow it & $42 \%$ \\
\hline $\begin{array}{l}\text { Manage the project to meet approved project plans and specifications in order to successfully pass inspections } \\
\text { and complete the final acceptance process }\end{array}$ & $27 \%$ \\
\hline Develop a succession plan that designates replacement staff for key positions & $15 \%$ \\
\hline Establish and implement effective quality-management procedures & $15 \%$ \\
\hline $\begin{array}{l}\text { Accurately complete all paperwork, retain it for required time frames, and submit it on schedule to ensure full } \\
\text { reimbursement for all eligible costs }\end{array}$ & $8 \%$ \\
\hline Finish the project within the required time & $4 \%$ \\
\hline
\end{tabular}

\subsection{Effective project management strategies}

The respondents were asked to provide information regarding the implementation of project management strategies by their DOT agencies. Multiple questions about the implementation level of various management strategies were included in the survey as a five-point Likert scale, from very low to very high implementation. The questions asked were about team qualifications, quality management, scope verification, communication plan, risk management, environmental planning, safety management, document management, and repair prevention. The results are presented in Figure 2.

As shown in Figure 2., roughly $60 \%$ of the respondents stated that their DOT agencies highly implement the strategy of team qualification in their projects, and about $20 \%$ stated that their agencies moderately implement it. Since a construction project's success is strongly dependent on the project team tasked with delivering it, the best-planned projects may fail to meet their objectives if the project team does not perform to the best of its ability (37). The effective development and integration of the project team is essential to the success of a construction project because it is responsible for the delivery of the defined scope of the project throughout its lifecycle. Unqualified team members result in decreased productivity, an increase in the number of reworks, and schedule and cost overruns [38, 39]. 


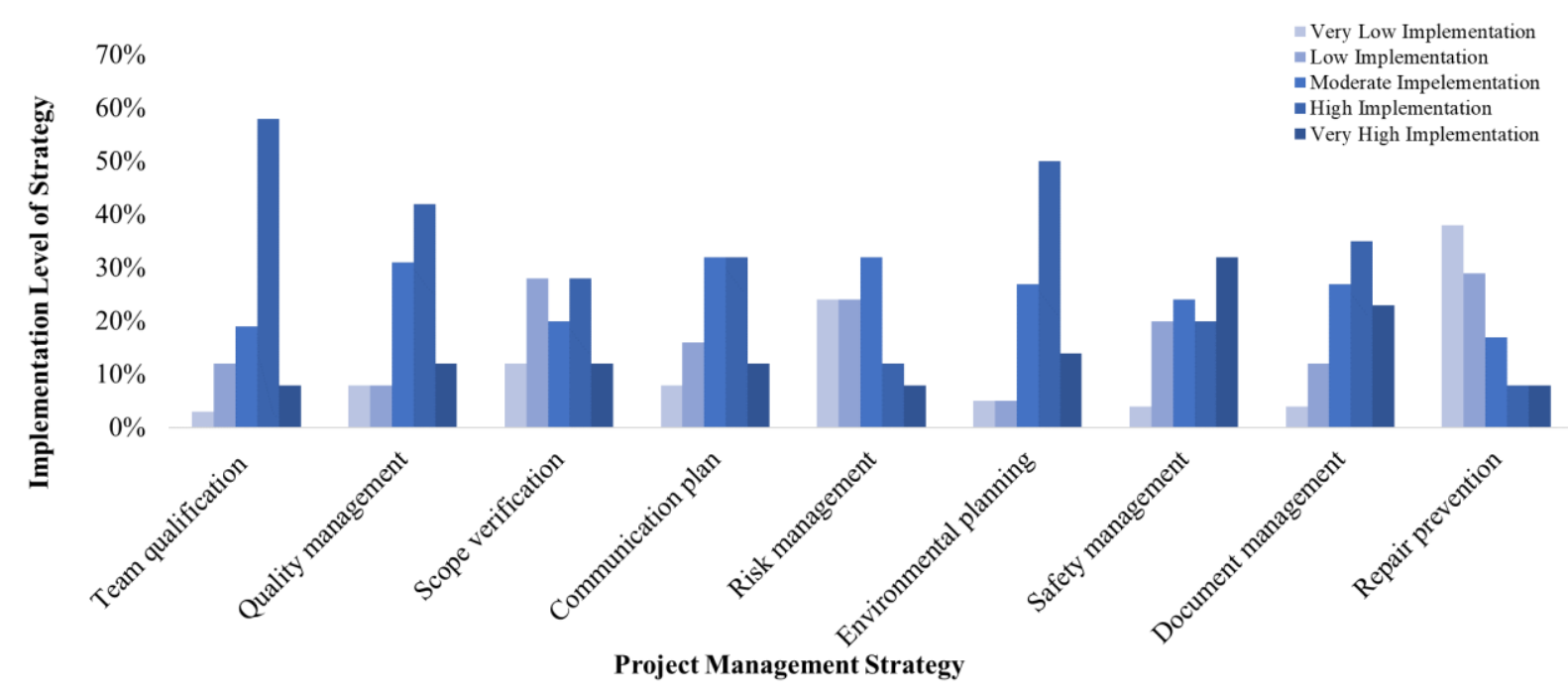

Figure 2. Implementation Level of Effective Project Management Strategies

The respondents were also asked to provide information about the implementation level of quality management strategies. Quality management strategy refers to the incorporation of all of the activities conducted to improve the efficiency, contract compliance, and cost effectiveness of the design, engineering, procurement, quality assurance (QA) and/or quality control (QC), construction, and startup elements of construction projects. Implementation of this strategy prevents failure to comply with the material, equipment, and construction specifications, and as a result prevents early failure of the infrastructure projects [40,41]. As shown in Figure 3, more than $40 \%$ of transportation agencies highly adopted quality management strategies in their projects, and more than $30 \%$ of them moderately implemented them.

Figure 2 indicates that one of the strategies that the respondents were asked about was scope verification, which refers to the process of formalizing the project parties' acceptance of the project scope. It requires reviewing the work products and results to ensure that all were completed correctly and satisfactorily (42). Scope verification strategy commonly occurs at the end of each project phase and as part of the project closeout process. Dicks et al. [43] believed that state DOT's implementation of the project scope verification strategy leads to significant improvement of the project's performance. As presented in Figure 2, approximately $30 \%$ of respondents described the level of implementation of the verification strategy as highly adopted by their agencies, while $20 \%$ described it as moderately adopted.

The survey asked the participants to provide information about the implementation level of a communication plan for their projects by their DOT agencies. The strategy of communication plan was defined as the process of driving alignment between the communications function and the organization's core objectives. This strategy should always include consideration of employees as the key audience. As many different parties are commonly involved in a construction project, it may be difficult to organize and align them toward the same vision and goal [44]. Figure 2 illustrates that roughly 35\% of the respondents believed that their agencies adopted a high level of communication plan strategy in their projects, and about 35\% indicated that their DOT agencies moderately implemented the strategy.

The survey participants were asked to provide information about risk management also. A risk management strategy provides a structured and coherent approach to identifying, assessing, and managing risk. It builds in a process for regularly updating and reviewing the assessment based on new developments or actions, the lack of which can result in undesirable consequences that seriously affect the project's performance $[45,46]$. As illustrated in Figure 2 , about $30 \%$ of the respondents indicated that their agencies moderately adopt risk management best practices, and 50\% indicated that their agencies' implementation of risk management strategy in their projects is inadequate. 


\section{Conclusion}

This study had two main outcomes associated with highway, bridge, and roadway state DOT projects. It determined the implementation level of effective project management strategies in transportation infrastructure projects, and it determined the implementation level of effective project management principles. The results demonstrated that team qualifications, quality management, environmental planning, safety, and document management are the project management strategies most widely implemented in state DOT projects. Team qualifications received the highest implementation level among the adopted strategies, and environmental planning and quality management were ranked second and third. The results also revealed that three project management principles of "ensure that the project is fully scoped," "Establish and maintain effective communication among DOT staff; develop an escalation process to resolve conflicts and issues," "Actively oversee consultants and contractors to ensure work is complete and timely and meets quality standards and regularly requirements" were recorded as the first rank accounting of $70 \%$ among the DOTs' management principles.

The results of this study will assist decision-makers and project managers in making key decisions pertaining to the selection of effective managerial strategies and principles that will deliver an infrastructure transportation project on time and on budget, and with high level of quality.

\section{Acknowledgment}

Louisiana Department of Transportation and Development sponsored this research project. The authors would like to thank the sponsor of this study and the practitioners and experts who devoted their time and effort to support the research team in completing this study.

\section{References}

[1] Love, Peter ED, Michael CP Sing, Lavagnon A. Ika, and Sidney Newton. "The cost performance of transportation projects: The fallacy of the Planning Fallacy account." Transportation Research Part A: Policy and Practice 122: 1-20, 2019. https://doi.org/10.1016/j.tra.2019.02.004

[2] CURT, "Construction Strategy: CURT's path toward LEAN project delivery," Construction Users RoundTable, November 2007

[3] El Asmar, M., Hanna, A.S. and Loh, W.Y. "Quantifying performance for the integrated project delivery system as compared to established delivery systems." Journal of Construction Engineering and Management, 139(11): 04013012, 2013. https://doi.org/10.1061/(ASCE)CO.1943-7862.0000744

[4] Habibi M, Kermanshachi S, and Rouhanizadeh B. "Identifying and Measuring Engineering, Procurement, and Construction (EPC) Key Performance Indicators and Management Strategies", 2019. https://doi.org/10.3390/infrastructures4020014

[5] Thomsen, A., Darrington, J., Dunne, D. and Lichtig, W. "Managing integrated project delivery," Construction Management Association of America, Mclean, VA, 2010.

[6] Silva, S.K., Warnakulasuriya, B.N.F. and Arachchige, B.J.H. "A Scale for Measuring Perceived Construction Project Success-Sri Lankan Perspective." Studies in Business and Economics, 14(1), 245-258, 2019. https://doi.org/10.2478/sbe-2019-0019

[7] Kermanshachi S, Safapour E. "Gap Analysis in Cost Estimation, Risk Analysis, and Contingency Computation of Transportation Infrastructure Projects: A Guide to Resource and Policy-Based Strategy Establishment". Practical Periodical on structural design and construction, 2019. https://doi.org/ 10.1061/(ASCE)SC.1943-5576.0000460

[8] Chovichien, V. and Nguyen, T.A., "List of indicators and criteria for evaluating construction project success and their weight assignment". 4th International Conference on Engineering Project and Production, 2013. https://doi.org/10.32738/ceppm.201310.0011

[9] Tuman, J. "Success modeling: A technique for building a winning project team." Proc., 18th Annual Seminar/Symposium, Project Management Institute, Montreal, Canada, 29-34, 1986

[10] De Wit, A. "Measuring project success: An illusion." Proceedings of $18^{\text {th }}$ Annual Seminar/Symposium, Project Management Institute, Montreal, Canada, 13-21. 1986.

[11] Pinto, J.k., and Slevin, D.P. "Critical factors in successful project implementation." IEEE Trans. Engineering management., 34(1), $22-$ 27, 1987. https://doi.org/10.1109/tem.1987.6498856

[12] Sohail, M., and Baldwin, A. N., "Performance indicators for 'microprojects' in developing countries." Construction Management in Economics, 22(1), 2004. 11-https://doi.org/10.1080/0144619042000186022

[13] Nguyen, H.T. and Hadikusumo, B., "Impacts of human resource development on engineering, procurement, and construction project success." Built Environment Project and Asset Management. (2017). https://doi.org/10.1108/BEPAM-04-2016-0010

[14] Kissi, E., Agyekum, K., Baiden, B.K., Tannor, R.A., Asamoah, G.E. and Andam, E.T. "Impact of project monitoring and evaluation practices on construction project success criteria in Ghana". Built Environment Project and Asset Management, 2019 https://doi.org/10.1108/JOPP-11-2019-0075

[15] Viswanathan, S.K., Tripathi, K.K. and Jha, K.N., "Influence of risk mitigation measures on international construction project success criteria-a survey of Indian experiences." Construction Management and Economics, 2019. 1-16. https://doi.org/10.1080/01446193.2019.1577987

[16] Narayan, S. and Tan, H.C., "Adopting Big Data to Forecast Success of Construction Projects: A Review." Malaysian Construction Research Journal, 6(1), 132-143. 2019

[17] Jafari A, Kermanshachi S, Safapour E, and Taghizezhad A. "Best Practices for State DOTs to Determine Project Delivery Time, Project management, and Ratio of Consultant to In-House Design". Technical report, 2019 
[18] Safapour E, Kermanshachi S, and Shirin K R. "Development of the Effective Communication Network in Construction Projects Using Structural Equation Modeling Technique". ASCE International conference on computing in civil engineering, 2019. https://doi.org/10.1061/9780784482438.065

[19] Project Management Institute., "A Guide to the Project Management Body of Knowledge (PMBOK@GUIDE)." 4th Ed. Newtown Square, Pennsylvania, 2008. https://doi.org/10.1556/9789634545019

[20] Rouhanizadeh B, Kermanshachi. "General Contractor Superintendent Skills, and Attributes for Career Success". ASCE Construction Research Congress (CRC), 2019.

[21] Müller, R. and Jugdev, K., "Critical success factors in projects: Pinto, Slevin, and Prescott-The elucidation of project success", International Journal of Managing Projects in Business, 5(4), 757-775, 2012. https://doi.org/10.1108/17538371211269040

[22] Rouhanizadeh B, and Kermanshachi S. "Challenges and Strategies Incorporated with Transportation Construction Inspection". ASCE construction research congress (CRC), 2019.

[23] Morrison, J., \& Brown, C., "Project management effectiveness as a construct: A conceptual study." South African Journal of Business Management, 35(4), 73-94, 2004. https://doi.org/10.4102/sajbm.v35i4.670

[24] Siemiatycki M. "Delivering Transportation Infrastructure Through Public-Private Partnerships: Planning Concerns". 2009. https://doi.org/10.1080/01944360903329295

[25] Zamenian, H. and Abraham, D.M. "Pre-Contract Project Scoping Processes: Synthesis of Practices". Technical report, (2016). https://doi.org/10.5703/1288284316192

[26] Kermanshachi S, Safapour E, Anderson S, Goodrum P, and Taylor T R B. "Establishment of Effective Project Scoping Process for Highway and Bridge Construction Projects". Practice Periodical on Structural Design and Construction 25(2), 2018. https://doi.org/10.1061/(ASCE)SC.1943-5576.0000427

[27] Le, T., Caldas, C.H., Gibson, G., Jr., and Thole, M., "Assessing scope and managing risk in the highway project development process." Journal of Construction Engineering and Management 135(9), 900-910, 2009. https://doi.org/10.1061/(asce)co.19437862.0000052

[28] Anderson S, Quiroga C, Overman J, Choi K, Sahu J, Kermanshachi S, Goodrum P, Taylor T, Li Y. "Effective project scoping practices to improve on-time and on-budget delivery of highway projects", Book, National Academy of Engineering, 2016. https://doi.org/10.17226/23398

[29] Kermanshachi S, Safapour E, Stuart A, Gudrum P, Taylor T, and Sadatsafavi H. "Exploring Current Scoping Practices Used in the Development of Transportation Infrastructure Projects". CSCE 12th International Transportation Specialty, 2018.

[30] State of Washington Joint Legislative Audit \& Review Committee (JLARC)., Washington State Department of Transportation's scoping and cost estimating for highway construction projects (Report 10-3, January 5, 2010.

[31] Kermanshachi S. "Decision Making and Uncertainty Analysis in Success of Construction Projects". PhD dissertation, 2016

[32] Cheng, E. W. L., H. Li, P. Love, and Z. Irani., "Network communication in the construction industry." Corporate Communications. International Journal, 6 (2): 61-70. 2001.

[33] Shirin K R, and Kermanshachi S. "Development of Project Communication Network: A New Approach to Information Flow Modeling". Construction Research Congress (CRC), 2018. https://doi.org/ 10.1061/9780784481271.042

[34] Dainty, A. R., and H. Lingard. "Indirect discrimination in construction organizations and the impact on women's careers." J. Manage. Eng. 22 (3): 108-118, 2006. https://doi.org/10.1061/(asce)0742-597x(2006)22:3(108)

[35] Kermanshachi S. "US multi-party standard partnering contract for integrated project delivery". Master Thesis, 2010

[36] Safapour E, Kermanshachi S, Shirin K R, and Tran D. "Identifying Effective Project-Based Communication Indicators within Primary and Secondary Stakeholders in Construction Projects". Journal of Legal Affairs and Dispute Resolution in Engineering and Construction 11(4), 2019. https://doi.org/10.1061/(ASCE)LA.1943-4170.0000332

[37] Safapour E, and Kermanshachi S. "Identifying Early Indicators of Manageable Rework Causes and Selecting Mitigating Best Practices for Construction". Journal of management in Engineering 35(2), 2018. https://doi.org/ 10.1061/(ASCE)ME.19435479.0000669

[38] Santoso, D.S. and Soeng, S., "Analyzing delays of road construction projects in Cambodia: Causes and effects." Journal of Management in Engineering, 32(6): 05016020. (2016). https://doi.org/10.1061/9780784482438.064

[39] Safapour E, and Kermanshachi S. "Investigation and Analysis of Human, Organizational, and Project Based Rework Indicators in Construction Projects". ASCE International Conference on Computing in Civil Engineering, 2019. https://doi.org/10.1061/9780784482438.064

[40] Hughes, C. H., "NCHRP synthesis 346: State Construction Quality Assurance Programs". Transportation Research Board, Washington DC, 2005.

[41] Jallan, Y., Lee, J. H. and Ashuri, B. "Synthesis of quality assurance practices of state dots for highway construction projects using alternative delivery". Construction Research Congress (pp. 650-659), 2018. https://doi.org/10.1061/9780784481295.065

[42] Kermanshachi S, Safapour E, Anderson S, Goodrum P, Taylor T R B, Sadatsafavi H. "Development of Multi-Level Scoping Process Framework for Transportation Infrastructure Projects Using IDEF Modeling Technique". Transportation Research Board 98th Annual Conference, 2018

[43] Dicks, E., K. Molenaar, and E. Gibson. "Scope definition of air force design and construction projects." Journal of Management in Engineering 33 (5): 04017028, 2017. https://doi.org/10.1061/(ASCE)ME.1943-5479.0000543

[44] Dainty, A, Moore, D, Murray, M., "Communication in construction: theory and practice:" (2006). https://doi.org/10.4324/9780203358641

[45] Tah, J. y Carr, V. "Knowledge-Based Approach to Construction Project Risk Management". Journal of Computing in Civil Engineering, 15(3), 170-177, 2001. https://doi.org/10.1061/(ASCE)0887-3801(2001)15:3(170)

[46] Schieg, M. "Risk Management in Construction Project Management". Journal of Business Economics and Management, VII (2), $77-$ 83, 2006. https://doi.org/10.1080/16111699.2006.9636126 